\title{
Determination of Specific Energy Consumption and Grain Size for Corn Grinding Using the Hammer Mill MB7,5
}

\author{
Ioan DROCAȘ*, Ovidiu MARIAN, Ranta OVIDIU, Adrian MOLNAR, Mircea MUNTEAN \\ University of Agricultural Science and Veterinary Medicine, Cluj Napoca, No 3-5, Calea Manastur Street, \\ 400372 Cluj-Napoca, Romania \\ *corresponding author:*drocas_i@yahoo.fr
}

Bulletin USAMV series Agriculture 71(2)/2014

Print ISSN 1843-5246; Electronic ISSN 1843-5386

DOI 10.15835/buasvmcn-agr: 10888

\begin{abstract}
Changing the degree to which animals feed is grinded can be done for hammer mills in several ways, namely: the use of sieves with different diameters, different hammers, different engine speeds.Grain milling energy consumption is influenced by the type of material used, its moisture content, size and type of hammers, sieves holes etc.In the present study we determined the influence of moisture and sieve mesh size on milling maize grain moisture of $11.1 \%$ and $17.6 \%$ using conventional hammer mill. Using three kinds of sieve apertures with a diameter of 4, 6 and $8 \mathrm{~mm}$ was determined from the specific grinding energy.
\end{abstract}

Keywords: corn grinding, grain size, hammer mill

Introduction. Cereals that are administered in feed must have a certain degree of grinding depending on the species of animals that are given.

In the process of grinding hammer mills are used to realize the shredding using impact between grain and hammer. This process is complex, fragmentation of the grains depends on a number of factors, such as grind material, its moisture, mesh size and mode of operation of the mill. These factors influence energy consumption in the grinding process.

Aims. The research objectives were to determine the working capacity of the mill when milling corn with a moisture of $11.1 \%$ and 17 , $6 \%$ and specific energy consumption using three types of sieves diameters of 4, 6, $8 \mathrm{~mm}$ and classic hammers (single notch).

Materials and methods. In the experimental research we used a grinding system controlled by a computer, equipped with a hammer mill (MB-
7.5). Energy consumption was determined using a module MAVOWAT 45. Along with measuring energy consumption the time and quantity of grinding was measured.

The mill was equipped with three types of sieves $\left(\mathrm{S}_{1}-4 \mathrm{~mm} ; \mathrm{S}_{2}-6 \mathrm{~mm} ; \mathrm{S}_{3}-8 \mathrm{~mm}\right)$.

Material moisture was measured before grinding using a moisture meter type Riela dete.

Results and Discussions. Experimental results on energy consumption, work capacity and specific energy consumption are presented in Table 1 and the graph in Figure 1.

Analyzing the data in Table 1 we can see that when grinding grain with higher moisture $(17.6 \%)$ the grinding power consumption is higher than in grinding corn with low humidity.

Increasing the sieve openings increases work capacity in a greater extent than the increase in power. The graph in Figure 1 shows that the specific energy consumption is higher if the humidity is higher and decreases with increasing of the diameter sieve. 
Tab. 1.

\begin{tabular}{ccc}
\hline Code & Power consumption $[\mathrm{kW} / \mathrm{h}]$ & Amount of material $[\mathrm{kg} / \mathrm{h}]$ \\
\hline C1-S1-U2 & 3.438 & 651.43 \\
\hline C1-S2-U2 & 3.230 & 692.31 \\
\hline C1-S3-U2 & 3.447 & 834.15 \\
\hline C1-S1-U1 & 3.231 & 633.33 \\
\hline C1-S2-U1 & 2.152 & 677.23 \\
\hline C1-S3-U1 & 3.371 & 900 \\
\hline
\end{tabular}

C1- hammer ;S1,2,3- sieves $(4,6,8 \mathrm{~mm})$

U1,2 -humidity
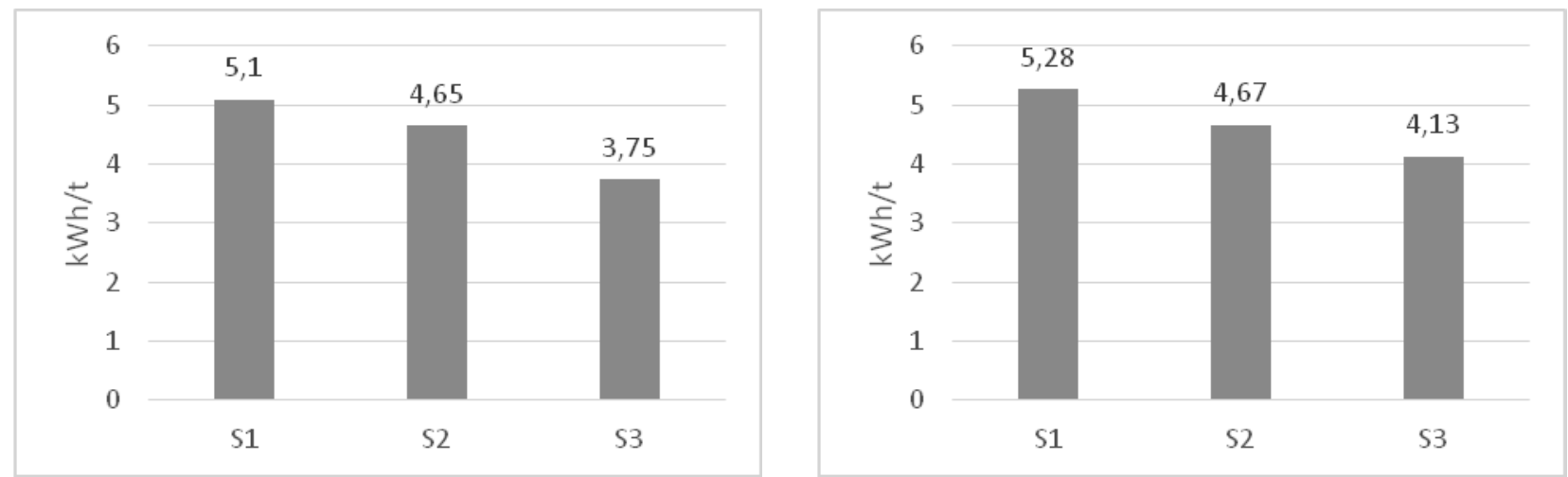

Fig. 1. The specific energy consumption when grinding corn at different humidity A - 11,1\% humidity; B- 17,6 \% humidity

Conclusion. Experimental tests have shown that maize grain grinding specific energy consumption decreases with decreasing humidity and increasing grain sieve diameter. The working capacity of the mill is higher when the humidity is low and the sieve openings are larger.

\section{REFERENCES}

1. Budăcan Ioan, I. Drocas, Pop D.,Influence of grain moisture content on milling parameters, Acta Tehnica Napocensis, Nr. 56, vol II, Cluj-Napoca

2. Budăcan I., Teză de doctorat - Cercetări privind morile cu ciocane din instalațiile agricole, UT Cluj-Napoca, 2013. 